\title{
No evidence for shallow shear motion on the Mat Fault, a prominent strike slip fault in the Indo-Burmese wedge
}

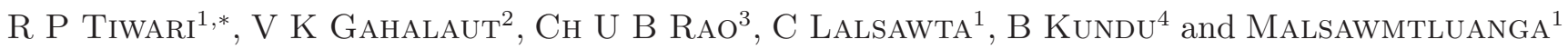 \\ ${ }^{1}$ Department of Geology, Mizoram University, Aizawl 796 004, India. \\ ${ }^{2}$ CSIR - National Geophysical Research Institute, Uppal Road, Hyderabad 500 606, India. \\ ${ }^{3}$ Department of Geography \& 8 Resource Management, Mizoram University, Aizawl 796 004, India. \\ ${ }^{4}$ Department of Earth and Atmospheric Sciences, National Institute of Technology, Rourkela, India. \\ *Corresponding author.e-mail: rptmzu@rediffmail.com
}

The motion between India and Sunda plates is accommodated along the Churachandpur Mao Fault $(\mathrm{CMF})$ in the Indo-Burmese Wedge (IBW) and Sagaing Fault in the Myanmar region. Within the IBW, the Mat Fault is the most prominent transverse structure with prominent topographic and geomorphic expressions. We undertook Global Positioning System (GPS) measurements across this fault to investigate the current deformation across it. Modelling of these observations using locking depth of up to 4 $\mathrm{km}$ yields no resolvable slip (dextral slip rate as $0 \pm 5 \mathrm{~mm} /$ year) across the fault. Due to limited spatial extent of the GPS measurements, it is not possible to comment on the status of deeper slip, if any.

\section{Introduction}

Relative plate motion along a long arc varies systematically depending upon the location of the Euler pole of rotation. The motion varies from one block to the other and the arc may be segmented by the transverse fractures/shear zones which accommodate relative motion between the adjacent blocks. These structural features may be located on the overriding plate or in the underlying plate. These features also influence arc morphology, seismicity, rupture extent and dynamics of the large earthquakes. The role of such structural features in the Himalaya and other plate margins has been emphasized by many investigators in recent years, e.g., in the Himalaya, by Armijo et al. (1986), Khattri and Tyagi (1983), Chen et al. (2004), Kapp and Guynn (2004), Gahalaut and Kundu (2012) and Gahalaut and Arora (2012). These features may be reactivated and may sometime produce devastating earthquake, e.g., September 18, 2011 Nepal-Sikkim earthquake in the Nepal Himalaya. This earthquake occurred on one such structural feature within the subducted Indian plate (Gahalaut 2012) and caused significant damage. In this article we have explored this idea in the Indo-Burmese arc. There are many transverse features in the approximately $\mathrm{N}-\mathrm{S}$ trending Indo-Burmese arc. However, the Mat Fault appears to be the most prominent among them (figures 1 and 2). The NW-SE trending Mat Fault can easily be traced on the satellite image of topography (from Google Earth), and on geomorphological and tectonic maps of the region (Nandy 2001). The Mat river crosses the Mat Fault and flows for a distance of $10 \mathrm{~km}$. We undertook GPS measurements to assess the present day motion across this fault. In this article we report the results of 6 years of campaign mode GPS measurements.

Keywords. Mat Fault; Indo-Burmese wedge; transverse feature; GPS measurements. 


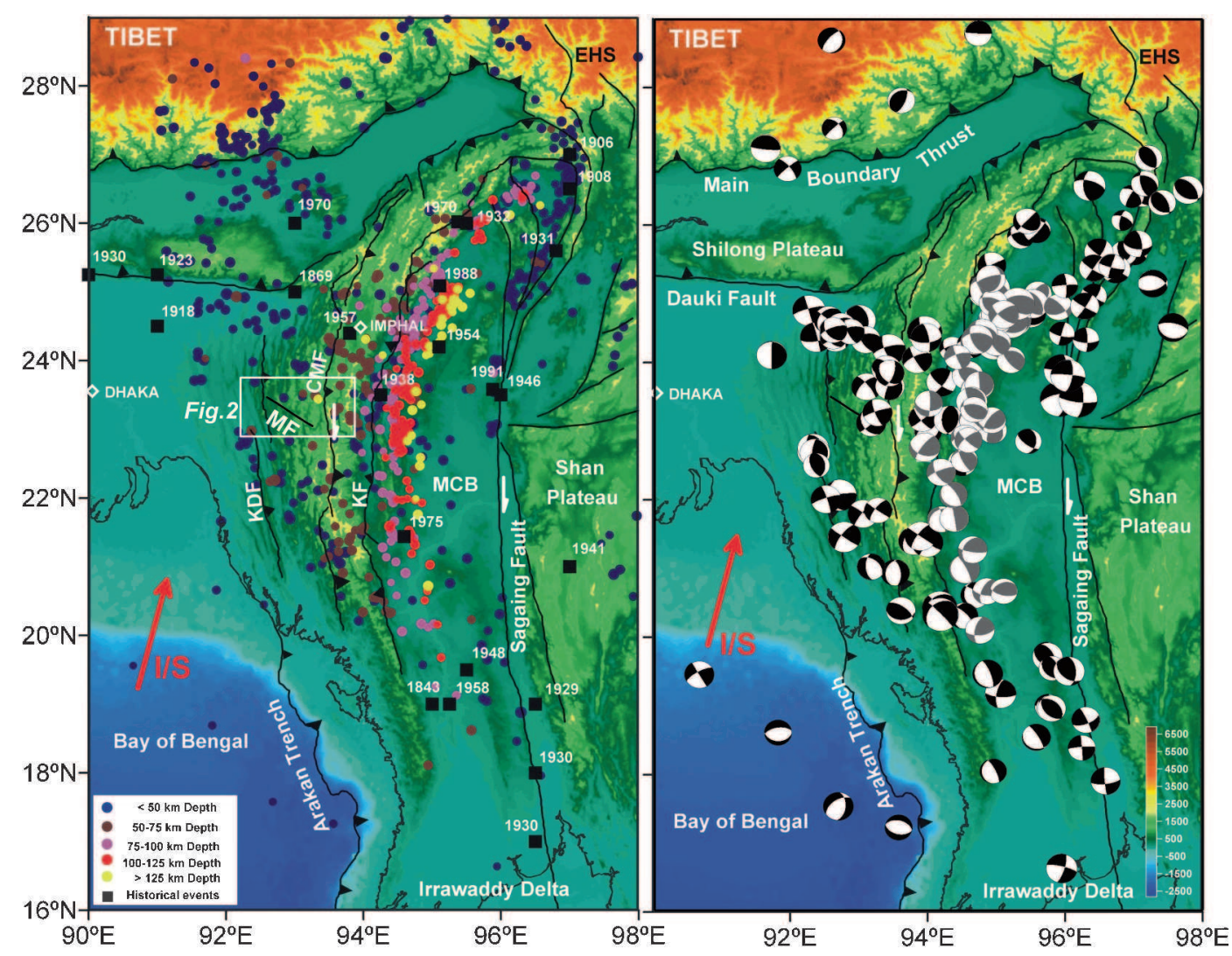

Figure 1. General tectonics, earthquakes and their focal mechanisms in the Indo-Burmese arc region. Strong earthquakes in the region are identified by their year of occurrence. Red arrow shows the India Sunda relative motion. MCB: Myanmar Central Basin, CMF: Churachandpur Mao Fault, KDF: Kaladan Fault, MF: Mat Fault.

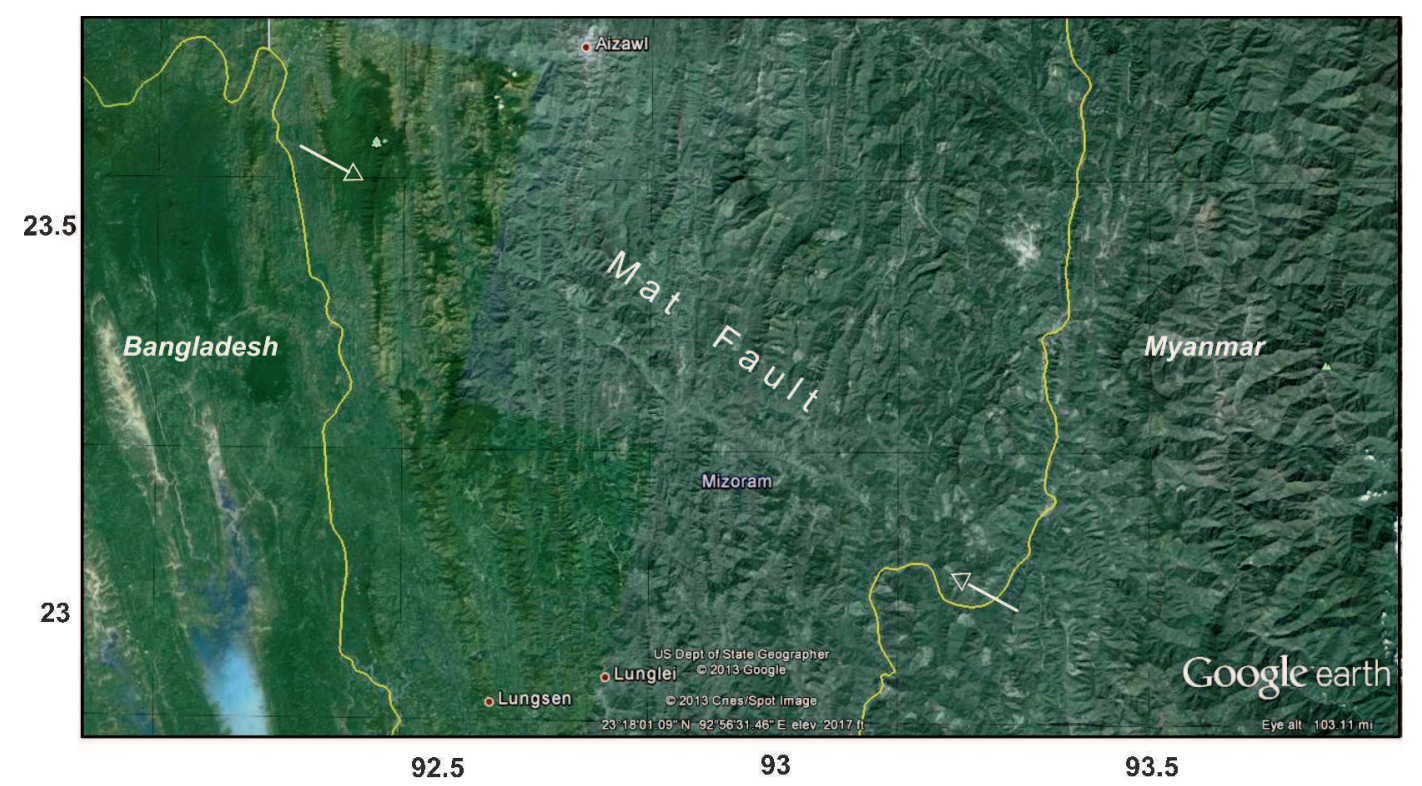

Figure 2. The Mat Fault in the Mizoram state of India, as seen on the Google Earth image.

2. General tectonics and geology of the IBW and the Mat Fault region

The India-Sunda plate boundary region consists of the IBW, Myanmar Central Basin, Sagaing Fault and is flanked by the Bay of Bengal sediments to the west and Shan Plateau to the east (Fitch 1972; Le Dain et al. 1984; McCaffrey 1992) (figure 1). The IBW is an arcuate sedimentary belt with north-south trending fold and thrusts and may 
be further divided into the outer and inner wedge and core (Maurin and Rangin 2009). The outer wedge rocks are lower Miocene submarine deposits, upper Miocene shelfal deposits to Plio-Pleistocene fluvial deposits. The inner wedge is composed of Eocene flyschs affected by $\mathrm{N}-\mathrm{S}$ trending dextral strike-slip faults. The core of the wedge consists of high-grade metamorphic rocks, tectonically imbricated with Mesozoic ophiolites and sedimentary sequences ranging from Late Triassic to Late Cretaceous (Bender 1983; Maurin and Rangin 2009). The Kabaw Fault, a back-thrust, marks the eastern margin of the IBW. The Myanmar Central Basin is a series of Cenozoic basins presently affected by an active tectonic inversion. The north-south trending Sagaing Fault separates the Myanmar Central Basin from the Shan Plateau and joins into the Andaman sea rift system which finally joins the Sumatra Fault System in the Sumatra region (Curray 2005). Plate reconstruction models suggest that the subduction of the Indian plate probably occurred until about $50 \mathrm{Ma}$ when the IBW was predominantly southeast-northwest trending (Hall 2002). After the collision of the Indian plate with the Eurasian plate, the entire Sunda arc, rotated clockwise to become predominantly north-south trending (Hall 2002). Though there are evidences of the presence of the subducted Indian slab under the IBW (Mukhopadhyay and Dasgupta 1988; Li et al. 2008; Steckler et al. 2008; Pesicek et al. 2010), subduction is not active presently. This has been brought out by the extensive GPS measurements across the entire arc (Gahalaut et al. 2013). These measurements suggest that about $16 \mathrm{~mm} /$ year of the India-Sunda relative motion of $35 \mathrm{~mm} /$ year is accommodated in the IndoBurmese wedge through dextral slip on the Churachandpur Mao Fault. Remaining motion of about $20 \mathrm{~mm} /$ year is accommodated on the Sagaing Fault (Vigny et al. 2003; Maurin et al. 2010).

The Mat Fault is located on the central part of the outer wedge of the IBW (figure 2). Geologically, this region is a part of Surma Basin. This is an area of folded sediments and is characterized by westerly convex, sinuous structural ridges and valley. This basin is wider to the north and narrower to the south. There are many NE-SW and NW-SE lineaments/faults in this basin. The NE Sylhet lineament/fault running from near Dhaka, Bangladesh to the northeastern corner of Bengal Basin demarcates the northwestern boundary of the Surma basins. Another NE trending lineament is Gumti Fault which cuts across the Bengal and the Surma basins. There are many such NE lineaments/faults in the southern part of Surma Basin (Mizoram) which show strike slip displacement of the fold axes along them. The structure of the
Surma Basin is characterized by a series of continuous and discontinuous N-S, NNE-SSW subparallel doubly plunging en-echelon regional anticlinal ridges and synclinal valleys formed of rocks of Suma, Tipam and Dupi Tila Groups. Fifteen major long anticlines and corresponding synclines in the widest part of the basin (Tripura-Mizoram area) have been delineated. Many of the anticlines bifurcate to form two anticlinal ridges with subparallel axial trends. The anticlines are mainly bounded on one (mainly eastern) or both flanks by longitudinal reverse faults which run close and subparallel to the crests of the anticlines. The magnitude of faulting generally increases towards east with the increase in intensity of folding. The individual structures are segmented by cross faults and conjugate oblique faults, some of which have strike slip components and have offset anticlinal axes and flank faults. Many of the northwest-southeast faults like Mat, Tuipui, Saitual and Sateek faults in Mizoram are sinistral whereas the north-south oriented Aizawl and Kaladan are dextral in nature (Nandy 2001; Tiwari 2002).

\section{Seismicity of the IBW and the Mat Fault region}

The seismicity in the IBW is quite complex and a simple interpretation may lead to erroneous result. Earthquakes in the IBW are confined at shallow to intermediate depth level and majority of them occur at depth greater than $70 \mathrm{~km}$ where they appear to define the Wadati-Benioff zone (figure 1). Under the thick outer and inner IBW, level of seismicity is generally low and the earthquakes define a very gentle eastward dipping trend surface at a depth of about 30-40 km (Kundu and Gahalaut 2012). However, an examination of the focal mechanisms of these earthquakes reveals that they do not occur at the contact surface between the wedge and the India plate, but within the India plate, as none of the nodal planes of these earthquakes coincide with the inferred gentle dip of the contact surface and that of the seismicity trend surface (Kundu and Gahalaut 2012). The orientation of the nodal planes of these earthquakes is consistent with the old geologic fabric of the Indian plate. The motion on these planes and the stress state is consistent with the relative motion between the Indian Sunda plates and all these earthquakes are of intra-slab type (Kundu and Gahalaut 2012) which occur within the subduced Indian plate due to its northward movement with respect to the Burma plate. Thus very few earthquakes occur within the IBW. The Mat Fault region is characterized by low seismicity and in the past 50 years no earthquake of $\mathrm{M}>4.5$ has 
occurred on the Mat Fault and no earthquake of $\mathrm{M}>5.5$ has occurred within $100 \mathrm{~km}$ from the fault (Sailo et al. 2011). In recent years, an earthquake (Mw 6.1) on November 21, 1997 in the southern part of Mizoram, occurred more than $100 \mathrm{~km}$ south-southwest of the Mat Fault. This earthquake had a focal depth of $54 \mathrm{~km}$ and involved reverse connected oblique motion on steep planes. As discussed above these earthquakes are of intra-slab type, which occur within the Indian plate. Even the Kaladan Fault which passes through the western part of Mizoram, does not exhibit seismicity. It is not sure whether small magnitude earthquakes are associated with the Mat Fault. Unfortunately, there is no local seismic network to ascertain this.

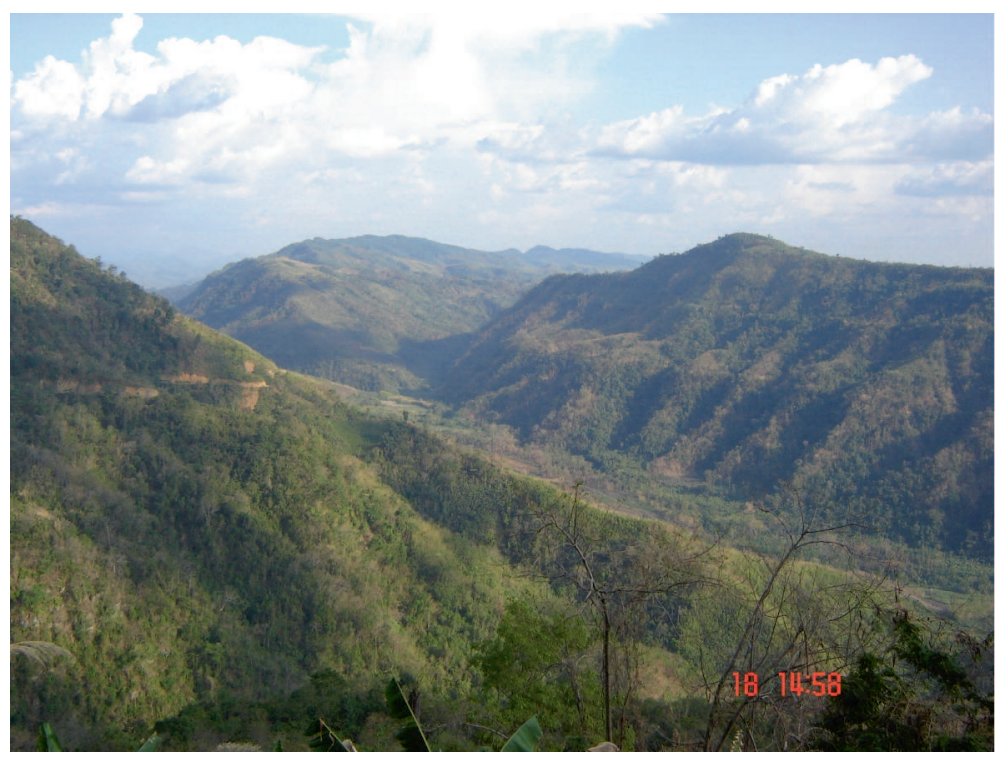

Figure 3. Field photographs of the Mat river which follow the Mat Fault near Thenzawl region in Mizoram, India.

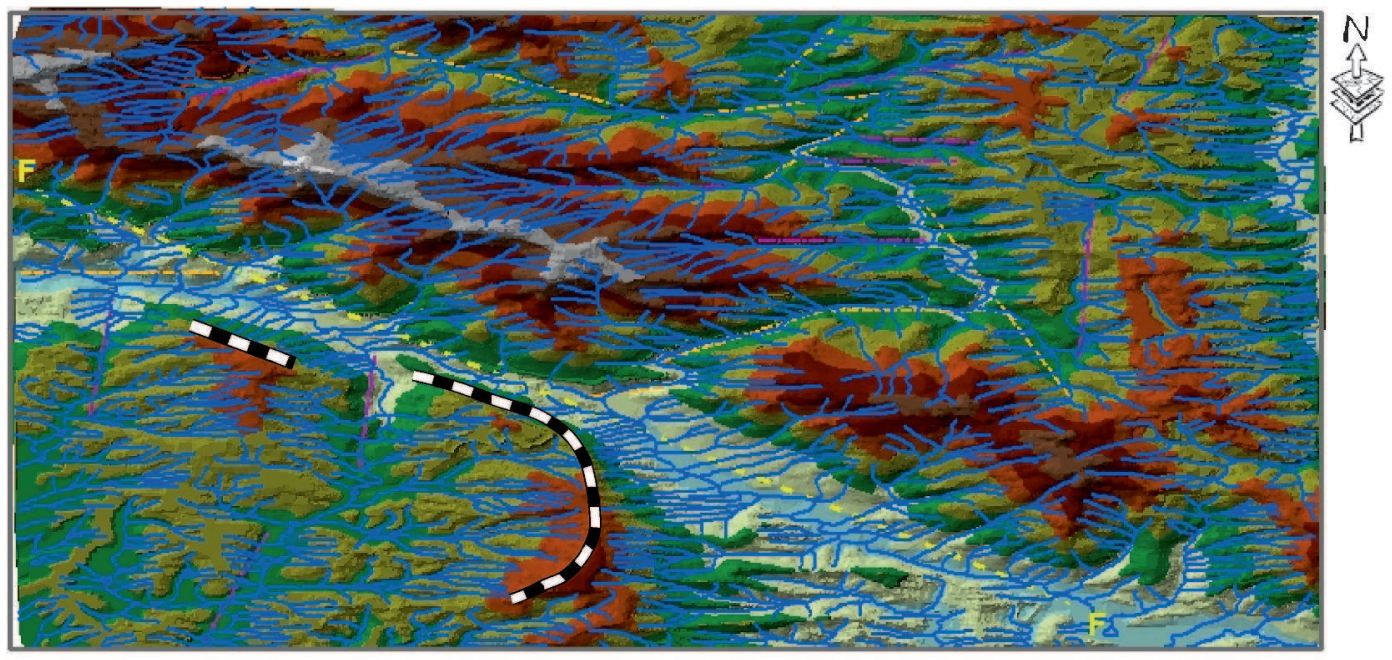

\section{Elevation in metres}
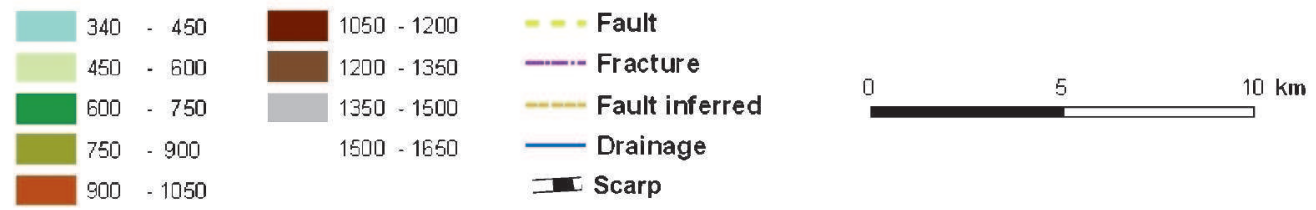

Figure 4. Triangulated Irregular Network (TIN) model of the Mat Fault and its surroundings showing the surface configuration and alignment of faults in preferred direction (thick yellow line indicates prominent Mat Fault). Yellow dashed line marks the Mat Fault. Other inferred faults/fractures have also been indicated. The fault scarp at two locations in the Mat valley is also shown. 


\section{Geomorphology and topography in the Mat Fault region}

The Mat Fault is clearly visible on the topographic maps, even on Google Earth Image and Triangulated Irregular Network (TIN) model of the area (figures 2 and 4). The Mat river, flows along this fault for nearly $10 \mathrm{~km}$ and has developed a wide course along the fault due to severe erosion. The unpaired river terraces can be easily seen on the left bank of the river course (figure 3). The development of about $700-800 \mathrm{~m}$ long and $60 \mathrm{~m}$ deep fault scarps and straight course of the river (figure 4) are the prominent geomorphic features in the area. The computed mountain front sinuosity values at selected sections in the fault zone varies between 1.6 and 2.0 which indicate that the mountain fronts along the fault zone show comparatively lesser tectonic activity (Bhatt et al. 2007).

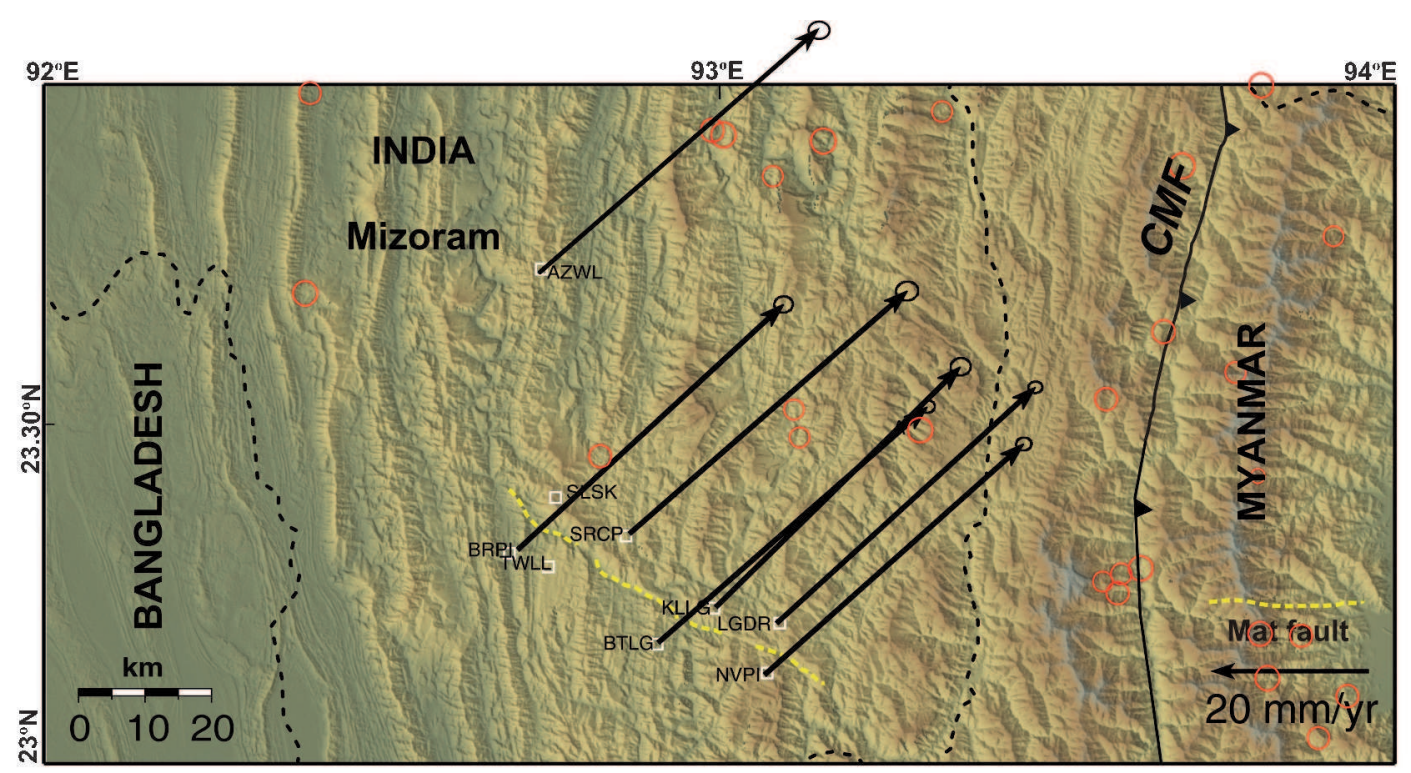

(a)

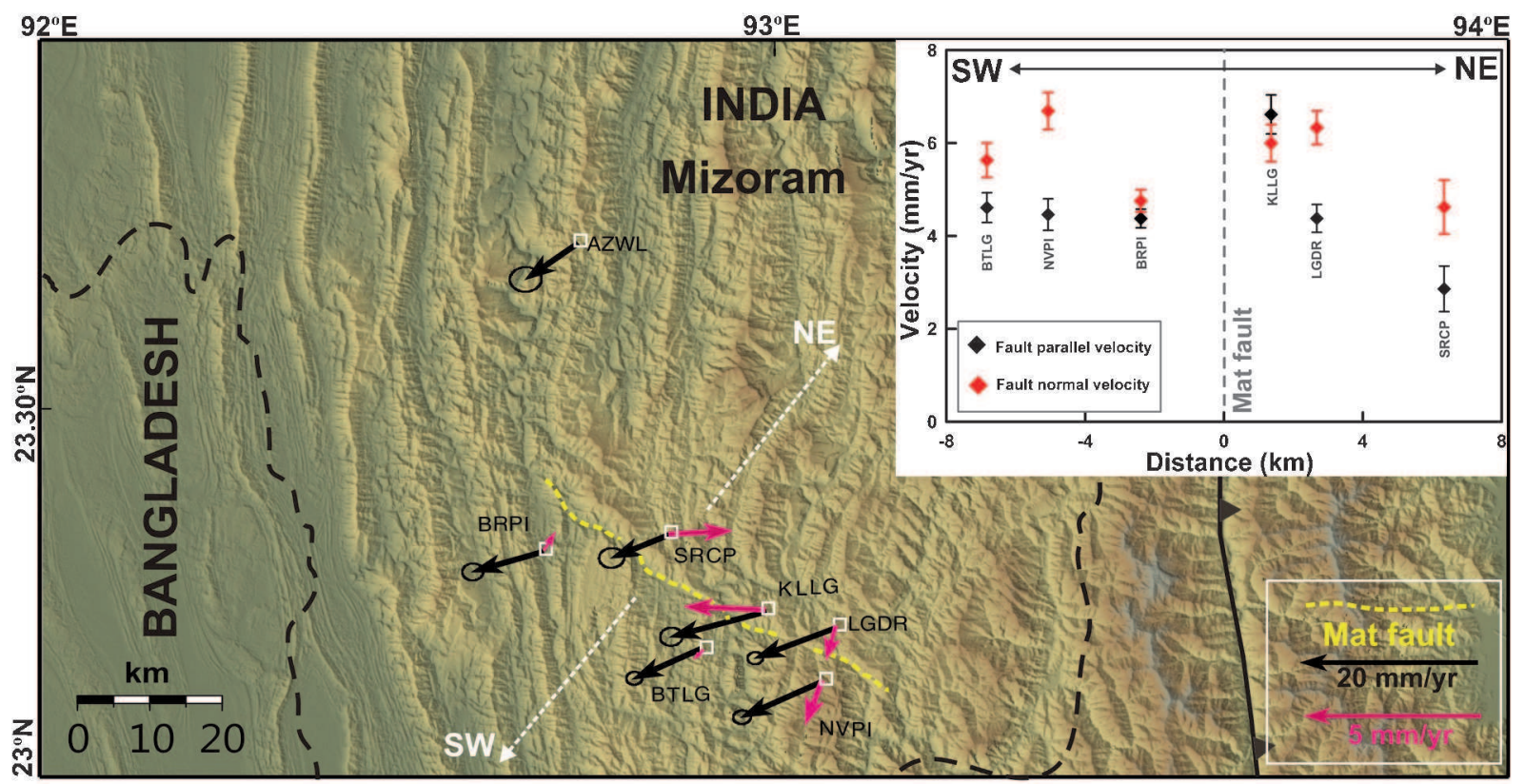

(b)

Figure 5. GPS measurements in the region. (a) Site velocity in the ITRF2005 with $1 \sigma$ uncertainty. The background topography is from SRTM. The earthquakes in the region are also shown. (b) Site velocity in the Indian reference frame (black arrows) and with reference to AZWL (pink arrows with different scale). To avoid congestion, we have removed the error ellipses from the vectors with respect to the AZWL. The inset shows the fault parallel and fault normal velocity. There is no significant variation across the Mat Fault. 


\section{GPS measurements across the Mat Fault}

In 2006, we initiated GPS measurements across the Mat Fault. We established eight sites across the Mat Fault, which were occupied for 3-4 days in each of the annual campaigns. Four sites each on either side of the fault were established. We chose only the middle part of the Mat Fault, where the fault has clear geomorphic expression. On the northwest and southeast extremes of the fault, it is not easy to locate the fault. All the sites are located on hard rock or on stable ground with proper monumentation for reoccupation. Unfortunately, two sites, namely SLSK and TZWL were vandalised in the second year of observations. We processed 6 years of data from the six sites along with data from several IGS sites around the IBW region using the GAMIT/GLOBK software (Herring et al. 2010a, b) for the estimation of site velocity in ITRF2005 (Altamimi et al. 2007) by constraining IGS reference station positions and velocities in the region to their reported values in that frame with standard errors provided by the IGS. Site velocity in India fixed reference frame is estimated using the Euler rotation pole of the stable Indian plate (Banerjee et al. 2008). The motion at these sites in ITRF2005 is about $46 \mathrm{~mm}$ /year towards $\mathrm{N}^{\circ} 9^{\circ}$ (figure 5a and table 1). The site motion across the Mat Fault may have at least two components, the northward motion of the Indian plate which is to be accommodated across the Sagaing Fault and further east, and any motion accommodated across the Mat Fault. We estimate the site velocity in Indian reference frame to get rid of the first component. In the Indian reference frame, all the sites show some southwestward motion of about $8 \mathrm{~mm} /$ year (figure 5b). Similar motion at all sites reflects inaccuracy in the Euler pole estimation which resulted in some residual plate motion at these sites. Another way of getting rid of this bias is to estimate the velocity in local reference frame, by selecting one of the sites in the neighbourhood. We estimated the velocity with reference to AZWL. All the sites now show motion towards west to northwest with varying magnitudes.

As we are mainly interested in the variation of velocity across the Mat Fault, we analysed the variation in fault parallel and fault perpendicular motion across the Mat Fault. In this strategy, any of the above two estimates (i.e., velocity estimates in Indian plate reference or velocity estimates with respect to AZWL) may be used. This strategy provides any motion across the fault by reflecting it in terms of the offset in the site velocity. Although there appears to be no significant motion across the fault (figure 5b) either in the fault parallel (strike slip) or in the fault perpendicular (dip slip) direction, we try to further confirm it from modelling. We modelled the fault as a buried infinite screw dislocation in an elastic halfspace, where during the interseismic period, aseismic slip across a vertical strike slip fault occurs at a rate $S$ below a locking depth $D$. For a displacement rate $u$ at a perpendicular distance $x$ from the fault, $u=(S / \pi) \times \tan ^{-1}(x / D)$ (Savage and Burford 1973). We assumed the Mat Fault to be vertical. We performed a grid search to find the minimum misfit between the observed and predicted fault parallel velocity in a profile across the Mat Fault by varying $S$ and $D$. The minimum corresponds to a slip rate of $0 \pm 5 \mathrm{~mm} /$ year (figure 6) in the locking depth range of $0-4 \mathrm{~km}$. It implies that there is no slip, at least on the shallow portion of the fault $(<4 \mathrm{~km})$. The error of $\pm 5 \mathrm{~mm}$ in the slip rate estimate corresponds to $\sigma$ error in the displacement rates at sites. As the depth of locking increases, the slip still remains close to zero but the uncertainty in this estimate increases. Thus, the slip on deeper portion of the fault $(>4 \mathrm{~km})$ cannot be resolved by the limited spatial extent of the GPS measurements. This implies that either the shallow part of the Mat Fault is currently inactive or the

Table 1. Estimated site velocity in ITRF2005 and Indian reference frame. Velocity of the permanent station at Aizawl is also provided. Relatively larger errors in the velocity estimate at AZWL are due to less amount of data. This continuous site was vandalized and discontinued in 2006. The estimates at this site are based on data during 2003-2006.

\begin{tabular}{|c|c|c|c|c|c|c|c|c|}
\hline \multirow[b]{2}{*}{ GPS sites } & \multirow[b]{2}{*}{$\begin{array}{c}\text { Longitude } \\
\left({ }^{\circ} \mathrm{E}\right)\end{array}$} & \multirow[b]{2}{*}{$\begin{array}{l}\text { Latitude } \\
\qquad\left({ }^{\circ} \mathrm{N}\right)\end{array}$} & \multicolumn{2}{|c|}{ ITRF2005 } & \multicolumn{2}{|c|}{ Indian reference frame } & \multirow[b]{2}{*}{$\begin{array}{c}\text { E-error } \\
(\mathrm{mm} / \mathrm{yr})\end{array}$} & \multirow[b]{2}{*}{$\begin{array}{l}\text { N-error } \\
(\mathrm{mm} / \mathrm{yr})\end{array}$} \\
\hline & & & $\begin{array}{c}\text { East } \\
(\mathrm{mm} / \mathrm{yr})\end{array}$ & $\begin{array}{c}\text { North } \\
(\mathrm{mm} / \mathrm{yr})\end{array}$ & $\begin{array}{c}\text { East } \\
(\mathrm{mm} / \mathrm{yr})\end{array}$ & $\begin{array}{l}\text { North } \\
(\mathrm{mm} / \mathrm{yr})\end{array}$ & & \\
\hline KLLG & 93.087 & 23.611 & 32.95 & 29.81 & -8.55 & -3.61 & 0.23 & 0.19 \\
\hline LGDR & 93.082 & 23.202 & 32.81 & 29.88 & -8.80 & -3.54 & 0.36 & 0.30 \\
\hline NVPI & 93.064 & 23.129 & 32.78 & 29.22 & -8.84 & -4.20 & 0.40 & 0.34 \\
\hline BTLG & 92.901 & 23.175 & 34.09 & 29.86 & -7.48 & -3.57 & 0.37 & 0.32 \\
\hline SRCP & 92.856 & 23.329 & 35.15 & 30.71 & -6.37 & -2.72 & 0.58 & 0.49 \\
\hline BRPI & 92.685 & 23.306 & 33.68 & 31.05 & -7.81 & -2.39 & 0.48 & 0.42 \\
\hline AZWL & 92.732 & 23.724 & 35.65 & 29.13 & -5.73 & -4.30 & 0.73 & 0.61 \\
\hline
\end{tabular}




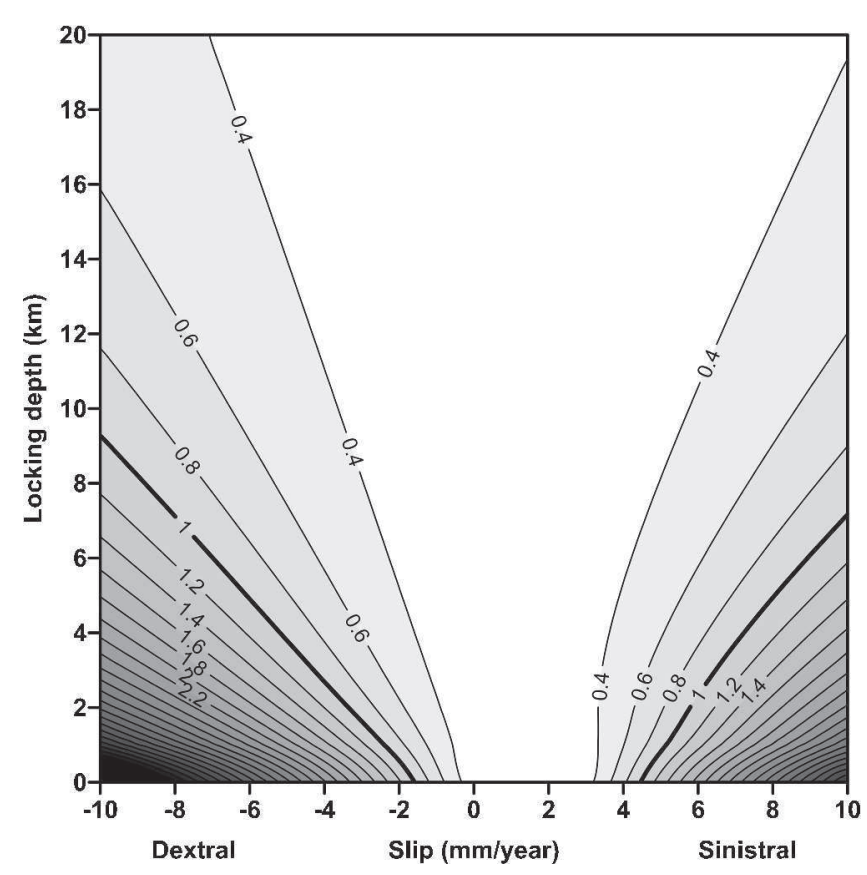

Figure 6. Misfit error in terms of $\sigma$ between observed and simulated fault parallel displacement at sites along a profile across the Mat Fault. Acceptable solutions, at 95\% confidence level, lie within the region bounded by the $2 \sigma$ contour. We varied the fault slip rate and the depth of locked fault.

motion across is too slow to be resolved by the current GPS network and we need constraints from nearby additional sites with longer data duration which can further narrow down the uncertainty in the slip rate and deeper slip.

It is possible that during the subduction process which resulted in the formation of the fold-andthrust belt of the Indo-Burmese wedge, the Mat Fault was formed to accommodate the variation of motion along the wedge. However, when subduction ceased, sometime $40 \mathrm{Ma}$ (Hall 2002), and the motion across the India-Burma plates became mostly arc parallel (Gahalaut et al. 2013), the Mat Fault probably became inactive or less active.

\section{Conclusions}

The Mat Fault is one of the most prominent structural features of the Indo-Burmese wedge. The geological and geomorphic signatures across the Mat Fault provide evidence about tectonic activity across this fault. There is general lack of earthquake activity along the fault in the past half century. Analysis of our campaign mode GPS measurements of 2006-2011 across the fault suggests that presently the shallower part of the fault (upper $4 \mathrm{~km})$ exhibit no slip $(0 \pm 5 \mathrm{~mm} /$ year $)$. But these measurements cannot resolve if the deeper part of the fault slips.

\section{Acknowledgements}

Authors thank Nibir Mandal, Associate Editor, Roger Bilham and two anonymous reviewers for their very constructive and helpful comments. Roger Bilham provided help in modelling and interpretation. They also thank Ministry of Earth Sciences, Govt. of India for financial support for this study vide MoES/P.O.(Seismo)/GPS/27/2004 and MoES/PO(Seismo)/GPS-1/2012.

\section{References}

Altamimi Z, Collilieux X and Métivier L 2007 A new release of the International Terrestrial Reference Frame based on time series of station positions and earth orientation parameters; J. Geophys. Res.: Solid Earth 112(9), doi: 10.1029/2007JB004949.

Armijo R, Tapponier P, Mercier J L and Tong-Lin H 1986 Quaternary extension in southern Tibet: Field observations and tectonic implications; J. Geophys. Res. 91 $13,803-13,872$.

Banerjee P, Burgmann R, Nagarajan B and Apel E 2008 Intraplate deformation of the Indian subcontinent; $\mathrm{Geo-}$ phys. Res. Lett. 35 L18301, doi: 10.1029/2008GL035468.

Bender F 1983 Geology of Burma; Beiträge zur regionalen geologie der erde. 16, Borntraeger, Stuttgart.

Bhatt C M, Chopra R and Sharma P K 2007 Morphotectonic analysis in Anandpur Sahib area, Punjab (India) using remote sensing and GIS approach; J. Indian Soc. Remote Sens. 35(2) 129-139.

Chen Q J T, Freymueller Z, Yang C, Xu W, Wang Jiang Q and Liu J 2004 Spatially variable extension in southern Tibet based on GPS measurements; J. Geophys. Res. 109 B09401, doi: 10.1029/2002JB002350.

Curray J R 2005 Tectonics and history of the Andaman sea region; J. Asian Earth Sci. 25 187-228, doi: 10.1016/j.jseaes.2004.09.001.

Fitch T J 1972 Plate convergence, transcurrent faults and internal deformation adjacent to southeast Asia and western Pacific; J. Geophys. Res. 77(8) 4432-4461.

Gahalaut V K 2012 M 6.9 September 18, 2011 Sikkim earthquake; Geomatics, Natural Hazards and Risk 2 $325-328$.

Gahalaut V K and Arora B R 2012 Structural control on along-strike variation in the seismicity of the northwest Himalaya; J. Asian Earth Sci. 57 15-24.

Gahalaut V K and Bhaskar Kundu 2012 Possible influence of subducting ridges on the Himalayan arc and on the ruptures of great and major Himalayan earthquakes; Gondwana Res. 21 1080-1088, doi: 10.1016/j.gr.2011.07.021.

Gahalaut V K, Bhaskar Kundu, Sunil Singh Laishram, Joshi Catherine, Arun Kumar, Devchandra M, Tiwari R P, Samanta S K, Ambikapathy A, Mahesh P, Bansal Amit and Narsaiah M 2013 Aseismic plate boundary in the Indo-Burmese wedge, northwest Sunda Arc; Geology 38(7) 591-594.

Herring T A, King R W and McClusky S C 2010a GAMIT reference manual, release 10.4: Cambridge, Massachusetts Institute of Technology, Department of Earth, Atmospheric and Planetary Sciences, 171p.

Herring T A, King R W and McClusky S C 2010b GLOBK reference manual, Global Kalman filter VLBI and GPS analysis program, release 10.4: Cambridge, Massachusetts Institute of Technology, Department of Earth, Atmospheric, and Planetary Sciences, 95p. 
Hall R 2002 Cenozoic geological and plate tectonic evolution of SE Asia and the SW Pacific: Computer-based reconstructions, model and animations; J. Asian Earth Sci. 2 $353-431$.

Kapp P and Guynn J H 2004 Indian punch rifts Tibet; Geology 32 993-996.

Khattri K N and Tyagi A K 1983 The transverse tectonic features in the Himalaya; Tectonophys. 96 19-29.

Kundu B and Gahalaut V K 2012 Earthquake occurrence processes in the Indo-Burmese wedge and Sagaing Fault region; Tectonophys. 524-525 135-146, doi: 10.1016/j.tecto.2011.12.031.

Le Dain, Tapponnier Paul A Y and Molnar Peter 1984 Active faulting and tectonics of Burma and surrounding regions; J. Geophys. Res. 89 453-472.

Li C, van der Hilst R D, Meltzer A S and Engdahl E R 2008 Subduction of the Indian lithosphere beneath the Tibetan Plateau and Burma; Earth Planet. Sci. Lett. 274 157-168.

McCaffrey R 1992 Oblique plate convergence, slip vectors, and fore arc deformation; J. Geophys. Res. 97 8905-8915.

Maurin T, Frederic Masson, Claude Rangin, Than Min U and Philippe Collard 2010 First global positioning system results in northern Myanmar: Constant and localized slip rate along the Sagaing Fault; Geology $\mathbf{3 8}$ 591-594.

Maurin T and Rangin C 2009 Structure and kinematics of the Indo-Burmese wedge: Recent and fast growth of the outer wedge; Tectonics 28 TC2010, doi: 10.1029/2008TC002276.

Mukhopadhyay M and Dasgupta S 1988 Deep structure and tectonics of the Burmese arc: Constraints from earthquake and gravity data; Tectonophys. 149 299-322.

Nandy D R 2001 Geodynamics of northeastern India and the adjoining region; ACB Publication, Calcutta, 209p.

Pesicek J D, Thurber C H, Widiyantooro S, Zhang H, DeShon H R and Engdahl E R 2010 Sharpening the tomographic image of the subducting slab below Sumatra, the Andaman Islands and Burma; Geophys. J. Int. 182 433-453.

Sailo S, Tiwari R P and Baruah S 2011 Seismotectonics of Surma Basin with special reference to Sylhet and Mat faults; Geol. Soc. India Memoir 77 185-193.

Savage J C and Burford R O 1973 Geodetic determination of relative plate motion in central California; J. Geophys. Res. 78 832-845, doi: 10.1029/JB078i005p00832.

Steckler M S, Akhter S H and Seeber L 2008 Collision of Ganges-Brahmaputra Delta with the Burma Arc: Implication for earthquake hazard; Earth Planet Sci. Lett. 273 367-378.

Tiwari R P 2002 Status of seismicity in the northeast India and earthquake disaster mitigation; Envis. Bull. Him. Eco. \& Dev. 10(1) 10-21.

Vigny C, Socquet A, Rangin C, Chamot-Rooke N, Pubellier M, Bouin M N, Bertrand G and Becker M 2003 Present day crustal deformation around Sagaing Fault, Myanmar; J. Geophys. Res.: Solid Earth 108(B11) 2533. 